UK Science Research Council, which has long since used its Engineering Board as an explicit means of fostering and improving engineering research in British universitics. Even the admirers of the Engineering Board acknowledge that it has had an uphill struggle, however. The National Science Foundation may have better luck, given the stronger tradition of research (as distinct from external consultancy) among engineering faculties in the United States. But nobody should think that the cooperative research centres will have a decisive effect. Many will no doubt be useful, but the funds available do not bear comparison with what the mission agencies spend on development contracts.

By the same tests, the proposal that there should be a National Engineering Foundation, with terms of reference similar to those of the National Science Foundation, is likely to fly like a lead balloon. Representative George Brown, the chief sponsor of the scheme, sees it chiefly as a way of goading existing institutions into action. But what action? As long as nobody is sure, a National Engineering Foundation would be simply a cosmetic device, a monument to the common Washington view that any problem can be solved by throwing money at it.

Yet there are constructive things that could be done. In the past twenty years, the character of engineering has changed enormously (especially in the United States), but the engineering schools remain much as they were. The best of them are prestigious places, and have adapted their teaching to changing needs. Elsewhere, teaching and the evolution of the curriculum have been hampered as much by the lack of teachers as money. If the cager beavers in Washington really seek to help, they would be well advised to concentrate on the education of engineers.

The consequences (so far) of the Finniston Inquiry into British engineering education may have been meagre, but the more flexible American university system could well benefit from taking stock of how it educates engineers. Why, for example, should not some engineering schools follow most medical schools in recruiting intending engineers from among people with good first degrees in relevant fields of study? These and other innovations deserve a fair hearing. Some useful ideas are, by all accounts, included in the report of the Secretary of Education and the Acting Director of the National Science Foundation, submitted two months ago but not yet published. Congressmen urging that something should be done about engineering might do worse than demand a sight of that document. But in the long run they must know that the health of the engineering profession depends intimately on the heaith of the economy, which is Congress's chief responsibility.

\title{
Poor outlook for British universities
}

One thing is certain about the future of the British university system - if it collapses, or if some parts of it collapse, these events will be recorded in the appropriate Annual Survey of the University Grants Committee (UGC) with decorum and gentility. These are the hallmarks of the latest document in this series, published last week (HMSO, Cmnd 8031) and covering the turbulent academic year 1978-79. The UGC records the successive chops and changes of public support for the universities under its wing, and does not in even the mildest language protest that this is not the way in which a motley collection of universities such as the British can be run sensibly, even economically. In the same way, the latest survey tells how the UGC responded to the decision a year ago that the recurrent grant to the universities would be slightly reduced in the academic year now starting by "advising universities . . . that their admission arrangements for 1980 should be so conducted that, if necessary, they could restrict the number of entrants in a way which would restrict the rate of increase in the total numbers of home undergraduates". The survey notes that the UGC "subsequently learned" of the proposals to increase the fees of students from overseas and says that "the unpredictable results of these new arrangements are causing universities much anxiety". The UGC as such stays on the fence, not adding even a mild expression of opinion such as "which we share". They order things differently in France (see page 381).

The truth is that the upshot of government decisions about British university finances in the past two years amounts to the most serious perturbation of the system since the onset of rapid expansion in the early 1960s. The bursars' departments of British universities have become almost as concerned to know what cheques will be in the next post as the most insecure small businesses. The comfortable quinquennial system of financing will not be revived in the foreseeable future, but even the system of rolling budgets offered as a substitute four years ago is vulnerable, from day to day, to quite minor changes of government policy. The UGC itself, in the course of distributing funds to the universities in its charge, frequently finds it necessary to keep back funds for dealing with unexpected problems (a sudden pay award, perhaps). The result is that individual universities sometimes do not learn until towards the end of an academic year whether they will finish up in the black or the red.

The coming academic year will be worse than ever, for the rules have been changed. The UGC's own recurrent grant has been reduced by the estimated cost of educating new students from overseas. Individual universities hope to make good the difference by the increased fees they will recover. It is too soon to known how successful they will be - not all the overseas students offered places have turned up as yet, while it remains to be seen how many will actually have the cash required of them. Some universities, a little surprisingly, seem confident that they will not be much worse off than last year. Others are despondent. It is, however, agreed that total income will decline. The UGC's own reaction is familiar, and understandable. Again it will keep some money up its sleeve, with the intention of helping out universities in trouble. As so often in the past, the successful universities will no doubt be penalized to help those that cannot recruit their expected quota of students from overseas. In the meantime, many university finance officers will be literally unable to make their budgets balance for the coming year. So they will skimp wherever they can, even on the quality of teaching.

Few outside the university system appreciate the debilitating consequences of this way of carrying on. The UGC no doubt regrets the way it has to keep its supposedly autonomous universities on tight and unpredictable purse-strings - but there is not a flicker of regret or even sympathy in the latest annual survey. This omission, tactful though it may be, is important and potentially damaging because there are already many in the universities who question the utility of the long-term survival of the UGC. For several decades, the committee has been held up as a shining example of public administration, a buffer between the government (first the Treasury, now the Department of Education and Science) and the universities. There may be no truth in the suspicion that the UGC is now less staunch a buffer, but its ready compliance with each tiny shift of public policy has given a different impression. That is merely one reason why it should seize what chances come its way to say where it stands. Another is that in the upheavals that lie ahead, some at least among British universities will look to the UGC for protection, not just from penury but from the structural changes there will be if the research councils eventually decide to concentrate their research grants on a smaller number of institutions (as the Merrison committee may well suggest). If the UGC persists in its present passive ways, however, it will be less able to offer help than the circumstances require. The larger and more successful universities will be able to look after themselves - and some would prefer to do so even as things are. There is no unalterable law that all universities must indefinitely survive. The UGC, however, seems well set to let them go without a struggle. 